\title{
When Policies and Marketing Systems Explode: An Assessment of Food Marketing in the War-Ravaged Balkans and Implications for Recovery, Sustainable Peace, and Prosperity
}

\author{
Clifford J. Shultz \\ Timothy J. Burkink \\ University of Nebraska \\ Bruno Grbac \\ University of Rijeka \\ Natasa Renko \\ University of Zagreb
}

Loyola University Chicago, cshultz@luc.edu

Follow this and additional works at: https://ecommons.luc.edu/business_facpubs

Part of the Business Commons

\section{Recommended Citation \\ Clifford J. Shultz II, Timothy J. Burkink, Bruno Grbac, Nataša Renko (2005) When Policies and Marketing Systems Explode: An Assessment of Food Marketing in the War-Ravaged Balkans and Implications for Recovery, Sustainable Peace, and Prosperity. Journal of Public Policy \& Marketing: May 2005, Vol. 24, No. 1, pp. 24-37.}

This Article is brought to you for free and open access by the Faculty Publications and Other Works by Department at Loyola eCommons. It has been accepted for inclusion in School of Business: Faculty Publications and Other Works by an authorized administrator of Loyola eCommons. For more information, please contact ecommons@luc.edu.

\section{(c) $($ () $\ominus$}

This work is licensed under a Creative Commons Attribution-Noncommercial-No Derivative Works 3.0 License. (c) American Marketing Association, 2005. 


\title{
When Policies and Marketing Systems Explode: An Assessment of Food Marketing in the War- Ravaged Balkans and Implications for Recovery, Sustainable Peace, and Prosperity
}

\author{
Clifford J. Shultz II, Timothy J. Burkink, Bruno Grbac, and \\ Nataša Renko
}

\begin{abstract}
The authors examine forces, policy failures, and the ensuing war and devastation of the marketing system of the former Yugoslavia. They provide an overview of the region and discuss food marketing's contributions to recovery. The authors then describe food-marketing institutions that have emerged from destruction and suggest some successful cases and best practices that can be leveraged to sustain peace and prosperity in the war-ravaged Balkans, as well as the broader global community.
\end{abstract}

Now sits expectation in the air.

-Shakespeare, Henry $V$

$\mathbf{T}$ he interactions of policy, policy failures, and war have horrific effects on markets, marketing processes, and consumer outcomes. Yet there is little research in the marketing literature that examines salient issues that are germane to war, marketing, and societal welfare (cf. Shultz

Clifford J. Shultz /I is a professor and Marley Foundation Chair, Morrison School of Agribusiness and Resource Management, Arizona State University (e-mail: atcjs@asu.edu). Timothy J. Burkink is Associate Dean and Associate Professor of Marketing, College of Business and Technology, University of Nebraska (e-mail: burkinktj@unk.edu). Bruno Grbac is Professor of Marketing and International Marketing, School of Business, University of Rijeka (e-mail: grbac@efri.hr). Nataša Renko is Professor of Marketing, Graduate School of Business and Economics, University of Zagreb (e-mail: nrenko@efzg.hr). The authors acknowledge the support of the U.S. Departments of State, Education, and Agriculture; the Fulbright Program; the Croatian Ministry of Science and Technology; the International Rescue Committee; the United Nations High Commissioner for Refugees; University of Tuzla; University of Zagreb; the North Atlantic Treaty Organization and the United Nations Stabilization Forces; University of Sarajevo; University of Split; University of Ljubljana; University of Rijeka; University of Pristina; the American Farm School; Agricultural Cooperative Development International and Volunteers in Overseas Cooperative Assistance; the Sustainable Technologies and Agribusiness Research Center; the Marley Foundation; and the gracious assistance and feedback provided by William L. Wilkie, Roger Dickinson, Morris Holbrook, Evangelos Vergos, Janez Damjan, Muris Čičić, Mahmut Osmić, Darko Jardas, Ray Marquardt, John O'Shaughnessy, Tony Pecotich, Betsy Conklin, Saša Brlek, and several other reviewers, logistical assistants, confidants, and informants who gave of their valuable time, frequently under difficult and dangerous circumstances, and without whom this research would not have been possible. For an unabridged iteration of this article, please contact the first author.
1997). This is rather alarming, given that more than 100 armed conflicts across the globe have claimed the lives of approximately six million people in the past decade, maimed millions of others, ruined entire economies, and destroyed institutions for recovery (e.g., Gleditsch et al. 2002; Peace Pledge Union 2000). These dreadful outcomes foment pervasive and ongoing deprivation and despondency, which in turn increase the likelihood of further violence and destruction (e.g., Model and Haggerty 1991). From a marketing perspective, that which can enable more benevolent rather than rapacious marketing processes often does not exist in warring or recovering economies; thus, individual consumer and societal outcomes are severely and adversely affected (e.g., Collier et al. 2003).

The wars and continuing problems throughout the former Yugoslavia have been among the most devastating of recent policy failures (e.g., Donja and Fine 1994; Silber and Little 1997; Tanner 1997). The disintegration of this former Communist country left more than 250,000 people dead and millions of others homeless and/or disenfranchised; at the time of this writing, tensions in some regions (e.g., eastern Slavonia, the Macedonia-Albania border, Kosovo) still remain high and have resulted in ethnic violence and an undercurrent of societal distress (e.g., Wood 2004). Similar to all war-ravaged areas, other tragic outcomes include decimation of the economic, political, and social infrastructures in the region, including the marketing system. For example, at the height of the war, industrial output in Bosnia and Herzegovina was $5 \%$ of the prewar output (The World Bank 2002b); today, the economy has "recovered" to approximately $50 \%$ of prewar production (Central Intelligence Agency 2004). ${ }^{1}$

1Places and people's names in the region are spelled many ways (e.g., Bosnia-Hercegovina, Bosna i Hercegovina, $\mathrm{BH}$ ); in general, we opted for commonly used English spellings throughout this article. Note also that Bosnia and Herzegovina are actually two distinct regions in one country, though we occasionally refer to only one region. 
The long, slow, and costly process of rebuilding societies and economies in the countries that have emerged from the disintegrated Yugoslavia create formidable challenges for long-term peace and sustainable prosperity. To compound the difficult rebirth, these economies struggle with the concurrent shock of transitioning from state to private control; now, the market largely directs economic activity, much of which the central government previously planned. Thus, in addition to recovering from war, these countries must also develop and change institutions to ensure successful transitions from command to market systems (Boger, Hobbs, and Kerr 2001).

In this article, we focus on the challenges and conditions of marketing in developing economies of the Balkans, moving from a war-ravaged command system to evolving market-driven peace-time systems. More specifically, we examine the extent to which one vital sector, food marketing, contributes to war recovery, mutually beneficial commercial processes, positive societal outcomes, and sustainable peace in the remnants of the former Yugoslavia.

\section{Balkans Maelstrom: Yugoslavia}

The Balkans, or Southeastern Europe, has been a confluence of migrations, political movements, empires, and war for millennia. The three dominant political, cultural, religious, and economic spheres of influence were the AustroHungarian, Ottoman, and Byzantine Empires; the vestiges of their religions, traditions, and administrative polices still greatly influence the region (e.g., Glenny 2000; Jelavich 1996). The land has endured centuries of strife. The word "Balkans" can be translated into "blood soil," and the term "balkanization" has entered the lexicon to suggest discord and fragmentation. Borders ebbed and flowed, and ethnic groups came and went with the movements of armies, political boundaries, religious missions, and economic opportunities. Although institutional remnants of the three empires remain most prominent, traces of Greek, Roman, and Celtic civilizations can also be found.

\section{Socialist Federal Republic of Yugoslavia}

The Socialist Federal Republic of Yugoslavia (hereinafter Yugoslavia) is at the heart of the Balkans (see Figure 1) and rose from the ashes of World War II (e.g., Rusinow 1977). ${ }^{2}$ It was forged from southern Slavic territories dominated by Serbs, Croats, and, to a lesser extent, Slovenes, with constitutional protection for minorities. 3 "Old" nationalism was forbidden. Previously bitter political, religious, and ethnic enemies were expected to become comrades in a Communist Yugoslav state, under the charismatic leadership of Josip Broz, who was known around the world simply as "Tito." Born to a Slovene mother and Croatian peasant

\footnotetext{
2Maps organized by Rekacewicz and Marin (2000) illustrate political evolution and boundary changes from 1815 to 1999, details of ethnic group locations before and after the Yugoslav Wars of the 1990s, points of intervention by the North Atlantic Treaty Organization during the Kosovo War, and trouble areas.

3Yugoslavia literally translates to "South Slavs," or "land of Southern Slavs."
}

father, Tito rose to organize and to lead the Yugoslav Partisans against the fascists during the Second World War. He was backed by the allies and, in 1945, was recognized as prime minister.

Tito's mark on history is well documented, but his effect on marketing is not nearly so widely recognized. Yugoslavia was unique in the Communist world. Breaking from Soviet dominance, Tito asserted Yugoslav independence in 1948, which eventually spurred more liberal interpretations of socioeconomic policy that were implemented from the mid1950 s to Tito's death in 1980 . The evolution from Orthodox Soviet interpretations of Communism to Socialist market principles resulted in a shift from an emphasis on central planning and state ownership, to social ownership and selfmanagement, and finally to contractual Socialism, which enabled some business decision making by workers' councils in conjunction with managers and the government. Heavy industry, large-scale production agriculture, education, and health care were socialized, but some private sector activities, including small-scale food marketing (e.g., restaurants, grocers), crafts, and services were not (e.g., Simmie and Deleva 1991). Core marketing concepts, such as the need for marketing research and the importance of satisfying the customer, were well understood in Yugoslavia as early as the 1960s (e.g., Rocco and Obraz 1963); these ideas grew in sophistication, practice, and influence over the next two decades (Rocco 1989), though not without dissent and reactionary movements if they were implemented too radically (e.g., Vugrinec-Hitrec 1983). The net result was a standard of living and personal freedoms that were not experienced elsewhere in the Communist world.

The principle of self-management warrants further discussion, because it had considerable impact on marketing and then consumption (e.g., Bicanic 1973; Macesic 1964; Perko-Separavic 1983). The policy was implemented to provide incentives to workers, to render various business processes more efficient, and, ostensibly, to tilt the economy in favor of consumers. Property ownership and capital were legally vested in workers, who then were empowered to make decisions about investment, production, marketing and distribution, and consumer outcomes. Article 10 of the Yugoslav Constitution concisely defined this system (1974) (Vojnic, Land, and Marendic 1989).

Despite some success, the Yugoslav model was doomed to fail. It never truly was a free market, or at least it did not approximate free market interpretations in the West closely enough. The entire system was politicized and sometimes sabotaged, and it suffered from comparative inefficiencies, lack of accountability, low levels of research and development investment, corruption, subsidies, a relatively small and poorly integrated Yugoslav market, and a deemphasis on profit as a goal (Lydall 1989). Therefore, although conventional wisdom frequently argues that the sources of conflict and the eventual demise of Yugoslavia have their roots in ethnic hostilities and the demise of Tito and his charismatic leadership (and occasionally his iron fist), a complementary explanation is that policies and ultimately the marketing system failed to deliver a reasonable standard of living that was commensurate with increasing consumer expectations (e.g., Pecotich, Renko, and Shultz 1994; see also Collier et al. 2003). 
Figure 1. Map of the Former Yugoslavia

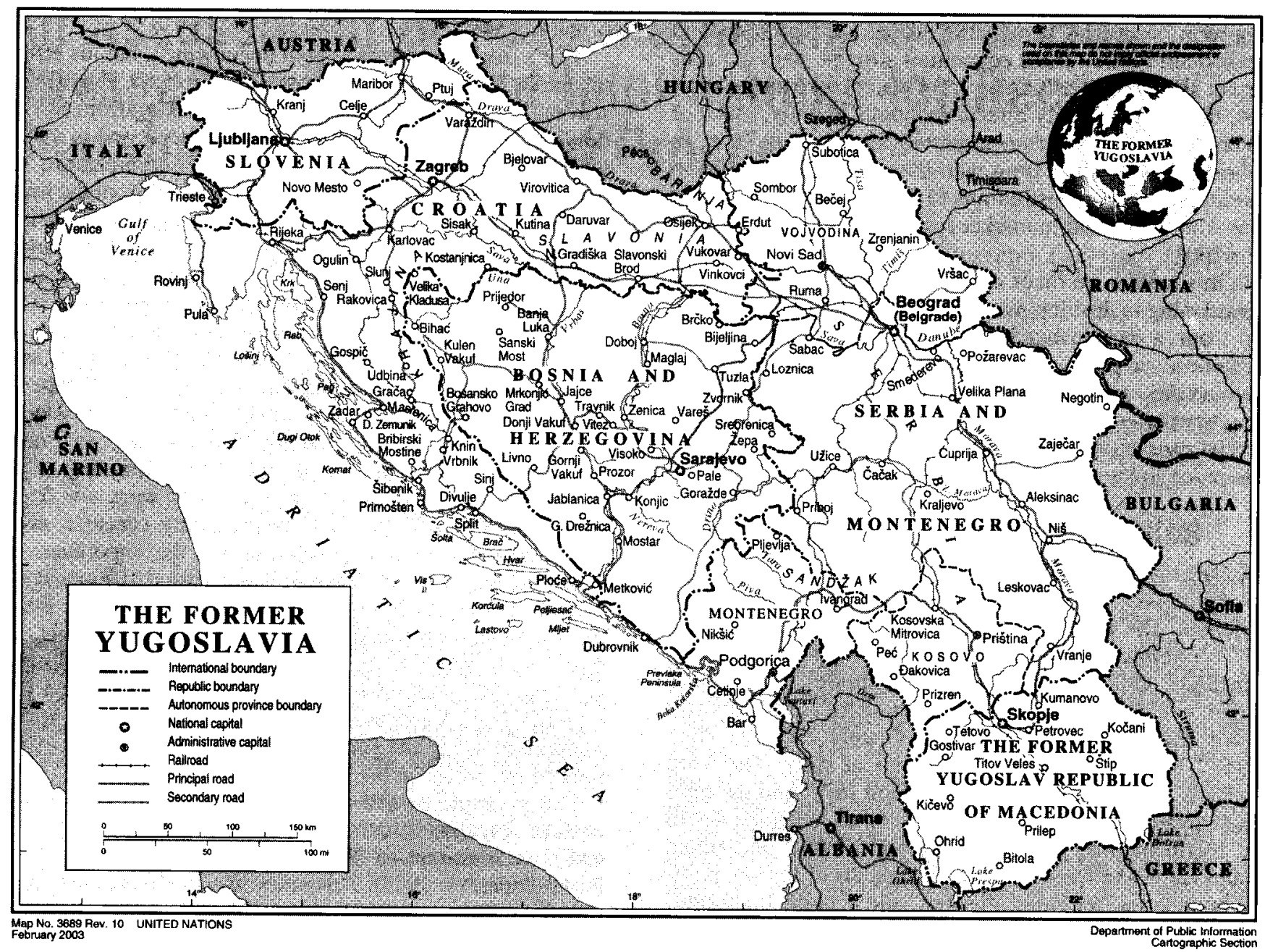

Source: United Nations (2003).

\section{People and Land}

The people are predominantly Slavs-that is, mostly Croats, Serbs, and Bosniaks, which are ethnic identities that are virtually synonymous with Roman Catholic, Eastern Orthodox, and Muslim, respectively (see, e.g., Doder 1978). ${ }^{4}$ It is not surprising that Slovenes and Macedonians, also Slavic peoples, are principally found in Slovenia and Macedonia,

${ }^{4}$ Nationality, ethnicity, and religion tend to be sources of confusion in this region. For example, almost all ethnic Croats or Croatians are Roman Catholic, but a person can hold a Croatian passport and be from any ethnic group and practice any or no religion. For example, Serbs who live in Croatia can be Croatian citizens, but when asked about their identity, they likely would respond "Serb," not "Croat." The term "Bosniak" is fairly new, emerging after the Bosnian war to denote citizens of Bosnia-Herzegovina without ethnic or religious attribution, but, in general, only Muslims seem to favor the term. These issues are particularly fuzzy in Bosnia-Herzegovina, which is the most ethnically mixed country, carved into the semiautonomous Serb Republic and also the semiautonomous Muslim and Croat Federation as part of the Dayton Accord (see Holbrooke 1998). respectively; they also tend to be Roman Catholic and Orthodox, respectively. Montenegrins, culturally more similar to Serbs and also Orthodox, are principally found in Montenegro. Ethnic Albanians are principally found in Kosovo and parts of Macedonia. Several other ethnic minorities are scattered throughout the region: Hungarians and are principally found in Vojvodina; Italians are principally found in Istria; and small numbers of Germans, Austrians, other Slavs, Greeks, Jews, and Roma are scattered throughout the region. A considerable amount of intermarrying has occurred for centuries, but though "pure" blood lines are difficult to trace, affinities and loyalties to cultural traditions are not.

Massive population shifts resulted from the wars and from new boundaries that formed in the wake of Yugoslavia's disintegration. This dislocation and resettlement of people had and still has a profound effect on markets and marketing processes. Political hotspots today tend to be those areas where large and ethnically diverse groups share communities by heritage and/or because they were 
relocated during the wars or armistices. These areas include eastern Slavonia; the formerly Serb-held "Krajina"; Kosovo (mostly ethnic Albanian but also sacred ground for Serbs, who are a substantial minority); and parts of the most ethnically mixed country, Bosnia (an amalgam of Serbs, Croats, and Bosniaks) and Herzegovina (an amalgam mostly of Croats and Bosniaks).

The terrain is rugged and varied. It is mountainous with some fertile valleys, and in the area of Slavonia and Vojvodina, it has fertile plains that are reminiscent of the United States Midwest. The coastal regions of Slovenia, Croatia, Montenegro, and a small protrusion of Herzegovina are rocky and less fertile. Distinct climates are present: continental and alpine in the interior and Mediterranean on the coast. These features affect the food-marketing systemwhat, when, where, how, and why food is grown, packaged, transported, and consumed - and the traditions that emerge from and preferences for various types of foods.

In summary, the region is extraordinarily complex on multiple dimensions. The most recent wars have contributed substantially to its tragic legacy (e.g., Cohen 1993; Didzarevic 1993; Glenny 1992; Silber and Fine 1997). The countries of the former Yugoslavia are undergoing a profound twofold transition: (1) from war to recovery and (2) from a unique model of central economic planning to several interpretations of considerably more laissez faire market economies. To date, results of recovery and transition remain mixed. In general, socioeconomic progress, and thus marketing and consumer welfare, in the region declines from west to east and from north to south; Slovenia and Croatia lead in development and transition indicators and ultimately a more successful turn to the market and to peace and prosperity (Central Intelligence Agency 2004; European Bank for Reconstruction and Development 1999), an issue to which we subsequently return.

\section{The (Food-) Marketing System}

As do other marketing scholars (e.g., Meade and Nason 1991; Wilkie and Moore 1999), we believe that systemic analysis is imperative to discover and to understand complex transitioning and recovering markets, such as the remnants of Yugoslavia, and that the longer-term objective is to provide solutions to multifarious challenges and to enhance more optimal societal outcomes. Effective marketing programs and behaviors are not likely to transpire without an understanding of the larger socioeconomic system in which such behaviors occur (e.g., Fisk 1981); thus, we are interested in the recovering marketing systems in the countries that composed Yugoslavia and, more precisely, the foodmarketing systems that assist or retard the revival of companies, communities, and countries. We accept that "the aggregate marketing system is recognized as different in each society, as an adaptive human and technological institution reflecting the idiosyncrasies of the people and their culture, geography, economic opportunities and constraints, and sociopolitical decisions" (Wilkie and Moore 2003, p. 118). However, some of those "adaptive" idiosyncrasies can also be dysfunctional, particularly in the case of warravaged transitioning economies. Therefore, it is imperative to understand key subsystems, such as food marketing. A better understanding of such subsystems can lead to best practices, which, if broadly implemented, benefit both the largest number of stakeholders within the system and other stakeholders external to the system of study that have vested interests affected by war, transition, and recovery.

\section{Revisiting Marketing Foci}

In many ways, our research reaches back more than a generation to some of the most compelling foci of marketing scholarship: "systems and groups of micro institutions,... the social context,... its role in the national economy,... entrepreneurial systems of multiple units,... and the processes of marketing" (Bartels and Jenkins 1977, p. 17), with particular emphasis on development (e.g., Drucker 1958; Holton 1953), desirable consumer outcomes (e.g., April et al. 1974), and, more broadly, the dynamism in that system that invokes progress and growth (Vaile, Grether, and Cox 1952). Given the state of global affairs, these same foci are perhaps even more prescient today. Effective marketing solutions to the devastation of war must consider specific enterprises and their relationship to the "social environment in different countries, the nature of social problems involving marketing, social goals for consumption and the resources for attaining them, and the relation of marketing to other business functions" (Bartels and Jenkins 1977, p. 20; see also Slater 1968; see also Hunt 1981, who notes the multidimensional and implicitly reciprocal nature of the system). Furthermore, a more systemic marketing perspective is important because its ethos encourages contributions from other viewpoints (e.g., Holbrook 1999), thus enabling integrative prescriptions when, too frequently, analyses and policy recommendations have been too narrow in scope, and because solutions to challenges prevalent in transitional economies require systemic perspectives (e.g., Klein and Nason 2002; Shultz and Pecotich 1997).

\section{Window to Society, Catalyst for Recovery}

Reconstruction of the domestic food-marketing systems is among the most urgent needs for war-ravaged, transition economies. A functioning food-marketing system is necessary simply for survival, but it is also requisite for muchneeded employment and trade in early transition (see Layton 1981), as well as more nuanced consumption experiences that give life meaning (e.g., Holbrook and Hirschman 1982). Agriculture and food marketing have strong social implications: They are important to rural poverty reduction and employment, and they also can be powerful engines for economic growth (Emmanuel Hidier, in European Bank for Reconstruction and Development 2002; see also Goldman 1974; Kumcu and Kumcu 1987; Slater 1974). In addition to stimulating domestic employment, food marketing is the dominant industry in many transition economies and is vital to recovering economies, and thus it represents the basic source of comparative advantage that these economies can leverage for trade, which in turn stimulates further institutional reform and economic performance (Thomas and Nash 1991; see also Abbott 1962; Gorton et al. 2003; Slater 1968).

Food marketing is a many-sided and systemic endeavor. It comprises the numerous tasks that affect the processes of production, distribution, pricing, promotion, and consumption of food as it passes through the supply chain from farm 
to fork. It also comprises, or at least addresses, the many factors that affect movement through the supply chain, including policy and government regulation, consumer decision making, environmental and cultural forces, marketing research, product development and branding issues, business-to-business marketing, corporate and government alliances, export and emerging market development, and social marketing through, for example, hunger relief and consumer protection. However, from producers to retailers, the entities that constitute the food-marketing systems throughout the remains of Yugoslavia and other transition economies often face formidable barriers. Market-driven private farms and cooperatives have replaced the collective farms throughout the countries that constituted Yugoslavia. Many production agriculture and food-marketing sectors that previously received heavy subsidies are now unable to operate profitably under free market conditions. Processors and manufacturers, suddenly without the benefit of state funding, struggle with adequate capitalization and are forced to limit production. Independent retailers are unable to maintain adequate inventories because of limited resources and credit. In addition, many retail transactions have moved to informal or parallel markets outside the government taxation and regulatory systems. Finally, consumers are faced with high unemployment and inflation, forcing them to spend the majority of their incomes on food.

Therefore, our objective is to assess the food-marketing system and to determine what contributions marketing can make to the recovery and stability of the region. Toward those desirable outcomes, we share findings from a longitudinal, multimethod, multicountry study.

\section{Methods}

We used interpretive methods, involving continuous and prolonged engagement by members of the research team, with a particular focus on intensive microcycle site immersion (Shultz, Pecotich, and Le 1994; see also Holtzman 1986) and with attention to the flow of food through the marketing channels (see also Dahringer 1983). This approach enables theory development through the identification of emergent themes from the study of a system in time, or microcycle-for example, a season or a production-delivery-consumption cycle. The marketing foci for this study are the activities evinced throughout the food channel, including producers, processors and manufacturers, distributors and retailers, and consumers. The specific, multiple techniques for engagement and primary data collection included site observation (e.g., Lincoln and Guba 1985), photographic recording (e.g., Holbrook and Kuwahara 1998), and depth interviews (e.g., McCracken 1988). We verified the findings through "persistent engagement, persistent observation, and triangulation across sources and methods" (Wallendorf and Belk 1989, p. 71).

Members of the research team have collected data since 1991 and during the wars (of independence or civil wars or wars of sedition, depending on the reader's perspective) since that time. In chronological order, the wars took place in Slovenia (briefly and with minimal damage), Croatia, Bosnia and Herzegovina, then Serbia and Montenegro, and finally Kosovo. Most recently, we have collected data dur- ing peace restoration and economic recovery. Although we have focused on and collected data throughout the region, some of the most compelling research findings emanated from our site engagement in the most heavily damaged areas: the Krajina; Vukovar and other towns on "the front"; Tuzla, Bihac, Sarajevo, Mostar, and smaller villages and makeshift market communities in Bosnia and Herzegovina; and Pristina and smaller United Nations Kosovo Forces and North Atlantic Treaty Organization-protected hamlets in Kosovo, which remains an unresolved flashpoint with sporadic fighting. In summary, we immersed ourselves in foodmarketing communities and venues that ranged from eradicated to undamaged - but still adversely affected - by the wars to those that were transitioning away from central economic planning.

Local residents and various food value-chain experts, whose ethnic composition matched that of the informants, assisted with interviews, logistics, and data collection in general. This empathic approach was especially valuable at sites where ethnic and/or political tensions were pronounced. Interviews were conducted with officials from government, companies (especially throughout the food value chain), academia, nongovernmental organizations, and consumers.

\section{Interpretations and Emergent Themes}

The interpretations and emergent themes from our fieldwork are a synopsis of site observations and interviews, sometimes framed in relation to timely and relevant literature.

\section{Peace and Prosperity Through Food Marketing}

This is a macro theme under which other emergent themes can be subsumed. Stability and agribusiness are closely linked; agriculture and food system revitalization are pivotal to short-term survival strategy and the foundation for longterm sustainable development and institution building (The World Bank 2002a). More specifically, the goal must be systemically effective agribusiness management that links production with markets, which enhances food security, employment, institution building, economic growth, global inclusion, sustainable development, technology transfer, life quality for a country's citizens, and, thus, stability within and among countries. However, impediments include large, historically agrarian, and production-oriented populations; population dislocation; production disruption, such as marketing channel fragmentation and interruption; limited systemic integration; capital shortage; managerial resistance to change and to global standards of excellence; failure to appreciate, to understand, or to respond to market forces; and underlying mistrust and hostility.

Findings from our fieldwork strongly support the notion that among all strata of society and across all regions that we studied, agribusiness development is a fundamental component of the plan for reconstruction. A strong production sector and systemic integration are recognized as critical for resettlement of populations; reestablishment of a viable food production, distribution, and export sector; and, more broadly, reestablishment of a practicable economy. It is hoped that targeted value-added agribusinesses develop into 
high-growth-potential industries, so that the region enjoys a sustainable competitive advantage. Reaching this long-term strategic goal requires an overhaul of the food-marketing system, from producer to consumer.

\section{Food Marketing: Sine qua non of Recovery}

Food is an integral part of life. Ensuring that people have adequate amounts of food is critical during and after the disruption of war. For example, $90 \%$ of Bosnia-Herzegovina's population was at least partly dependent on humanitarian food aid during and immediately after the war (The World Bank 2002b). Throughout the region, among the first institutions literally to rise from the ashes of destruction were food-marketing establishments. ${ }^{5}$ Members of our research team were among the first noncombatants allowed into Bihac after the siege was broken. Food-marketing endeavors were especially notable, substantiating our assumptions about the necessity and primacy of food marketing. The most prominent areas of activity and exchange amid the rubble were commercial "institutions": a burek kiosk in front of a razed church; 6 a provisional vegetable stand in front of another ravaged building; and a Volkswagen Golf festooned with scrounged chocolates, bread, cigarettes, coffee, and brandy. ${ }^{7}$ We emphasize that the revitalization of food markets, however crude, occurred before churches, schools, other companies, and government buildings were rebuilt or reopened.

The importance that people attach to food and food consumption goes well beyond basic sustenance to represent an important aspect of culture and subculture. In Bihac and elsewhere, we discovered that food-marketing venues, in addition to providing sustenance, are imperative for rebuilding communities; they enable pleasant consumption experiences and provide a sense of normalcy through the daily rituals of consuming food and drink. Consider another example from Bihac: a makeshift café in front of a bulletriddled, sacked auto repair shop. This auto shop-turned-café enabled locals to "take the coffee," which loosely translates to sitting for an extended leisurely period in the company of friends to enjoy a light snack, gritty and black coffee, and perhaps brandy or beer and thus to enjoy a respite in an otherwise extremely difficult environment. Such venues and consumption experiences help define Bosniaks and others in the region as a people; they conjure fond memories of better times and normalcy, and they render them human (for a similar observation in a Romanian context, see Belk and Ger 1994 , p. 126). The quick restoration of such institutions, regardless of how ramshackle the facility was after and even

\footnotetext{
5Our inclination is to argue that they were the first institutions, and our findings support this assertion, but perhaps we could have found exceptions.

${ }^{6}$ Burek is a traditional dish, prepared in pans, composed of phyllo dough, ground meat, and/or cheese, and it is frequently sold and served by the slice.

${ }^{7}$ We thought that this opportunistic merchant was especially clever. He would collect what he could scrounge in Croatia, drive to Bihac-passing through several checkpoints and on dilapidated roads-place his merchandise on the roof and hood of his car, sell it all, return to Croatia to scrounge for more goods, and then return the next day, open for business; he would do this day after day.
}

during the war, was paramount to the collective psyche of the people and the fragile society that was being rebuilt.

\section{Brands and Tastes of Foods: Ties that Bind}

Except in cases of extreme deprivation (e.g., concentration camps in Borovo and Srebrenica and some locations that were under siege, such as Bihac), it appeared that basic nutritional requirements were being met throughout the region, and many consumers were pursuing more diverse, high-quality foods, including familiar brand names that were not available during the war. Food and food brands are important consumption symbols, which can "represent and institutionalize the values and beliefs of a culture" (Aaker, Benet-Martinez, and Garolera 2001, p. 492; see also Douglas and Isherwood 1978). Therefore, markets, food stores, and restaurants offer products and services commensurate with food preferences, traditions, and consumer lifestyles as they do in less politically volatile environments (e.g., Marquardt and Burkink 2002); in that sense, they can serve as links to estranged people and groups.

This theme was apparent during visits to food markets in Vukovar. Located in eastern Slavonia (Croatia) across the Danube from Serbia, Vukovar was among the first and most devastated casualties of war and the site of some of the most brutal and bitter fighting. Atrocities were common, and memories of the suffering remain fresh. Ten years after the Siege of Vukovar, the city was slowly being rebuilt, but evidence of the war was virtually everywhere, and many buildings were still in rubble or severely damaged. Tensions still run high, and in general, the community continues to be segregated along ethnic lines-namely, Croat and Serb. Therefore, progress in Vukovar may serve as a predictor for other areas. One site visit and series of interviews was notable when a member of the research team interviewed sales clerks and customers at a small, typical grocery that was approximately the size of a convenience store in the United States. The clientele was unique, insofar as there were both Serbs and Croats. A member of our research team delicately asked, "Is it common for both Serbs and Croats to shop at this store?" Two clerks, both women-one Serb, one Croat-responded. The first stated, "For us, the issue now is good quality products at good prices. This market has both (good products and prices) so whether we are Serb or Croat doesn't matter [the second concurred and both smiled]."

Thus, the tastes and brands of food can serve to bond groups that might otherwise be adversarial. Managers of successful food companies who were interviewed throughout this study understand this reality and regard markets beyond their political and ethnic boundaries; old and recent enemies are viewed as potential markets, not targets for protracted hostility. Successful food marketers have (re)developed markets with their former adversaries such that both parties win. On the outskirts of Tuzla and Pristina, two food retailers-one a grocer and the other a restaurateur-were spared during the war simply because they had added value to the dominant ethnic community before the war. The owners of both establishments still live as representatives of an even smaller ethnic minority in their original communities, and to date they have not been victims of violence or persecution. 
However, we must also add that we did encounter hostility on occasion. A member of our research team was subjected to curses and other aggressive acts for using a term for bread ( $k r u h$ versus hleb) that was not favored by the particular ethnic group. Nevertheless, a broader trend was clear: Commonalities for food preferences, food shopping behavior, and consumption were bringing people together. Again, this has not been lost on larger food companies. Many managers of food-marketing firms have made strategic decisions to reenter markets throughout the countries of the former Yugoslavia as soon as possible, both through exporting and direct investments in factories and distribution networks. This decision to sell products and to increase markets was contrary to sentiments that were expressed by many nonbusinesspeople throughout the region, including many in the government and universities who only wanted to look to the West (the European Union [EU], the United States, or their own Diaspora) for investors, investments, markets, and other opportunities. The public sentiment for cooperation seems to lag behind corporate interests; still, in general consumers throughout the region like their brands regardless of their countries of origin.

Before the war, Yugoslavs enjoyed many popular domestic brands, such as the ubiquitous Vegeta, a type of seasoning. Today, Podravka, a newly privatized Croatian company, successfully markets the Vegeta brand throughout the countries of the former Yugoslavia. Instead of viewing these brands as products of the enemy, consumers throughout the region welcome them and even seek them out as something familiar and comforting. Agrokor, perhaps the largest Croatian agribusiness firm, had already purchased an ice-cream factory in Bosnia-Herzegovina and was planning to increase exports of its popular Ledo brand (ice cream) and Jamnica brand (bottled water) and to expand investments throughout the region, including into Serbia. One senior official from Agrokor informed us, "We know that the consumers in these regions know and like the (Agrokor) brands and will return to these brands as they strive toward normalcy."

This reentry strategy by food-marketing firms can help reintegrate the region. It is "a part of the peace plan," according to a Croatian manager who worked for an Austrian-owned distributor of consumer packaged goods, Allgemeine Waren Treuhand; he suggested further that people throughout the Balkans are oriented to certain brands and flavors, and the "tastes of food [unite] people." The symbolism of a Croat working for an Austrian company that was expanding its interests deeper into the Balkans was not lost on us. Although none of us believed that this portended the reemergence of the Austro-Hungarian Empire, many consumers and retailers have great confidence in Austrian, German, and other European brands as well as the organizations that own the rights to these brands and the systems that bring them to the Balkans. Europeans-namely, Germans, Italians, and Austrians-know the "temperament" of the Balkans and, in turn, are confident that they can manage companies there and repatriate profits. Finally, many people throughout the region have traveled to and perhaps have lived in and were employed as guest workers in the EU for extended periods. These same people frequently have returned with raised performance expectations for goods and services.

That specific foods and food brands serve as carriers of cultural meaning cannot be reasonably refuted. Purveyors of many former Yugoslavian brands recognize that the cultural meanings embedded in their brands are a source of competitive advantage. Consumers increasingly view these brands and brands beyond the Balkans as anchors to a predictable, quality marketing system that adds value and enhances life quality. That is, they are pressing to link their system to the systems of the EU and the global economy. This evolving food marketer-consumer relationship is a critical finding: It is rudimentary to opening up regional markets; it is critical to reconstruction; and it helps rebuild individual relationships, value chains, markets, and societies.

\section{Channel Fragmentation and Consolidation}

In general, the development of marketing channels, as with other economic institutions, declines from north to south and from west to east. 8 This continuum of development is a reflection of the level of prewar development and the intensity, duration, and recency of the fighting. Indeed, a country's aggregate marketing channel structure is related to its level of economic development (e.g., Olsen and Granzin 1994; Sharma and Dominguez 1992; Stern and El-Ansary 1996). For example, channels in Slovenia and, to a lesser extent, Croatia are consolidating and organizing rapidly, whereas in Bosnia-Herzegovina and Kosovo, channels are highly fragmented.

A substantial amount of food in the region is distributed through short channels, often directly from producer to consumer. Many retail transactions occur in the many open-air markets or in small food stalls or "micro" stores that support the habit of daily shopping for food. However, there is a noteworthy shift occurring as hypermarkets and other large food stores become more prominent. With few exceptions, these retailers are based in Western Europe; they are largeapproximately 100,000 square feet - and carry a wide variety of imported products. In Ljubljana, Slovenia, these hypermarkets and other chain retailers have replaced more than $90 \%$ of independently owned retailers in the past five years. Given Slovenia's economic progress relative to the rest of the region, it may be that similar changes in food retailing will occur next in Croatia, followed by BosniaHerzegovina and the other recovering Balkan countries. Indeed, a similar (r)evolution is taking place in Croatia at the time of this writing.

8Macedonia provides a partial exception. Bordering Greece, and thus the EU, Macedonia has a direct conduit to a well-developed marketing system and benefits considerably from that direct link. Furthermore, Macedonia endured virtually no war devastation, though simmering tensions between Albania and Macedonia and some disenfranchisement by the Albanian minority in Macedonia are disconcerting and cause some foreign marketers to be somewhat wary. It also is important to note that Macedonia, a predominately Orthodox country, has an affinity with Orthodox Greece (despite disputes about ownership rights to the name "Macedonia"); Serbia, Bulgaria, and Romania, also predominately Orthodox, share this bond as well. Thus, because of tradition as well as proximity and resources, all these countries are looking to Greece for marketing-system direction and partnerships. 
Wholesalers also are emerging to organize channels. The majority of Allgemeine Waren Treuhand's business is in Croatia, but it is now penetrating Bosnia-Herzegovina, Macedonia, and even Serbia, which (as historians will note) never really favored an Austrian presence in the region. In general, in the twenty-first century, Serbs like Austrian products, brands, service, and reliability, and the Croatian Ministry of Agriculture plans to organize an unorganized market by constructing six wholesale produce markets throughout the country. This is an attempt to recapture the $90 \%$ of fruits and vegetables traded through illegal markets. Another objective is to improve product quality by improving the efficiency of bringing products to the market in a timely manner. However, as domestic retailers, such as Agrokor's Konzum, and European supermarkets and hypermarkets continue to expand, these wholesalers will face stiff competition and may become obsolete.

Channels are also fragmented at the input end, most notably by the inability of manufacturers to secure adequate supplies. For example, Skok Trade, a processing firm in Macedonia, is only at $50 \%$ capacity, primarily because of input problems. Frukta, a much smaller and more entrepreneurial Macedonian fruit and vegetable-processing firm, has had more success by organizing inputs through contracts with farmers. The owner/manager of Frukta finds that farmers prefer working with smaller, private companies, such as his, because compared with the former state-owned firms, they are more likely to "pay on time." The contracts require the farmers to use specific seed stock, specify quality control, and provide minimum prices, but he pays the market price if it is higher. He shares information with his suppliers about the price situation, including his margin structure, which "pacifies them."

Population displacement is another important factor in channel fragmentation. Millions of people were driven from their homes and farms as a result of the wars. The resettlement of these people from refugee camps, as well as from other countries, is ongoing, but it is proceeding slowly. There are still one million displaced people in BosniaHerzegovina (more than $25 \%$ of the total population), and many of these people were involved in agricultural production. As a result, agricultural production in BosniaHerzegovina was at $20 \%$ of prewar levels in 2002 ; more recent estimates have not changed substantially.

Many of the rural refugees would like to return to their farms, but they are faced with multiple barriers, including ownership disputes, land mines, and a lack of capital necessary to begin production again. However, the primary constraint is the lack of accessible markets. For example, before the war, dairy farmers sold their milk to a Sarajevo-based government dairy for processing. This facility was destroyed during the war, leaving the "milkers" without an outlet for their product. Dairies outside BosniaHerzegovina have filled the void, leaving the small producers without an outlet for their milk. The decimation of much of the upstream agribusiness value chain is a major barrier to reviving agricultural production.

Whereas producers are concerned with market availability, some agribusiness processors and manufacturers are concerned with their reliance on importing inputs. The Podravka Group is the largest food manufacturer in Croatia and one of the largest in Eastern and Central Europe. Danica, Podravka's processed meats division, is unable to meet consumer demand for its products or to keep its plants near capacity, because it is not able to source adequate amounts of raw materials, including livestock and/or fresh meat. The wars decimated the livestock sector, forcing manufacturers, such as Danica, to rely on imports from other European countries, which is subject to multiple import restrictions.

This concern for limited domestic supply of livestock is echoed at Lijanovici, a privately owned meat-processing company located in Herzegovina. The company has attempted to overcome supply problems by backwards integration: It owns some of its own farms and also works with "cooperating farms" to which it provides stock and veterinary services. However, the company still must import most of its supply, so Lijanovici is pressuring the government to develop domestic livestock production. Two of the owners are in high-ranking government positions. According to them, "getting the money is not the problem, but distributing to the farmers is a problem." They predict that in the near future, "we will see more government stimulation of agriculture," but they were quick to add that they will not wait for it. Instead, Lijanovici is an entrepreneurial marvel, seizing opportunities to create its own food-marketing channel mechanisms; raising capital from the World Bank's International Finance Corporation, the Croatian Diaspora in Germany, and elsewhere; building factories with current International Organization for Standardization specifications; creating a trucking fleet with Daimler cooperation; employing local people; and tailoring food products, delivery systems, and marketing communications in response to the arcane needs of Serbs, Muslims, and Croats. In many ways, the company is perhaps a model for other companies; this is an issue that we subsequently address.

\section{Targeting and Developing Competitive Advantages}

Restoration of farm production and linking to markets is a short-term priority; however, many government officials and entrepreneurs are also strategically focusing on developing targeted value-added agribusiness industries to fuel longer-term economic growth and stability. Among the sectors identified are specialty "Mediterranean" products, such as wine and olive oil; "healthy" products, including bottled water and organic produce; and traditional or "trusted" products with which consumers are familiar and have an emotional bond.

A substantially agrarian population working on small farms (less than three hectares) ${ }^{9}$ results in fragmented production and high costs, ironically making Croatia, for example, a net importer of food. Nonetheless, the farmland is diverse and has tremendous productive potential. Along the Adriatic coast, products, including grapes, honey, and olives, dominate. Grains, such as wheat and corn, grow in the more continental climate of the interior. Because the country never widely adopted pesticides, the government has established organic agriculture and ecotourism as major strategic initiatives for business development. Throughout

\footnotetext{
${ }^{9} \mathrm{~A}$ hectare equals approximately 2.5 acres.
} 
the region, organic foods are frequently mentioned as a source of sustainable, competitive advantage. Most supporters of the organic initiative point to high product value to offset low productivity and burgeoning markets in Western Europe and the United States.

Vegafruit, a privately owned fruit and vegetableprocessing company that is located in Bosnia, is already developing a strong business in natural foods. The chief executive officer started this company in 1994, after escaping from a Serbian-controlled prison camp in Doboj. From very austere beginnings, Vegafruit has grown into the largest fruit-processing firm in Bosnia-Herzegovina, with 600 full- and part-time employees. Overall, Vegafruit operations directly affect thousands of people, including fulltime and seasonal employees, farmers, and their families. The region is suited for growing healthy food because policies and geography (e.g., a protective mountain range) have kept the area relatively free of pollutants. The factory meets ISO 9001 standards in manufacturing. The implementation of a globally recognized food safety program (i.e., Hazard Analysis Critical Control Points) is the next intended step in continuous improvement. The management team positions Vegafruit as a "quality product" and exports $30 \%$ of production to "choosy Westerners" in the United States, the EU, and soon Australia.

Much of Vegafruit's success can be attributed to systemic integration with the region and to links in Europe and the United States. The company has formal contracts with 1200 individual farmers who grow the products. It also works with three cooperatives, two of which are Germansponsored co-ops; the Germans, through a humanitarian organization, provide seeds and expertise. Vegafruit also owns 60 hectares and controls all processes with farmers, especially regarding ecological issues. Elements of its strategic plan include managing relationships with farmers, both domestically and internationally; increasing output by $25 \%$ annually; moving into "organics," as certified by reputable foreign governments (it is working with the Swedish government and has several products ready for certification, including rosehips, blueberry, blackberry, and raspberry); and focusing on and developing Vega brand, which offers the highest margins.

The case of Vegafruit provides insights into how a new, viable, and natural and/or organic foods industry might evolve in a region that possesses the requisite natural resources, is close to major markets, is given latitude by a more market-oriented government, and is sensitive to global standards of safety, production, and quality. However, appropriate public policy must continue to nurture such development. Vegafruit has been the beneficiary of many international assistance programs, including the U.S. Agency for International Development. To the credit of multiple forces, it is now a viable private enterprise, adding value to the local community and local and export markets.

\section{Food-Marketing Archetypes}

Before the war, the Yugoslav system was administered through large, integrated, state-owned agrikombinats, with local representation for managing the marketing mix; some small (essentially "mom and pop") private retailers in the forms of restaurants, food shops, and grocers also were per- mitted. With the disintegration of that system and cessation of war, firms now tend to cluster into five archetypes across food marketing and agribusiness in general: Hopeful Desperates (disenfranchised, without requisite skill and/or resources), Dinosaurs (large, hanging on to old paradigms), Tycoons (large, market oriented), Oldies but Goodies (established, but struggling), and Phoenix Entrepreneurs (usually new, small, market oriented). A description of each archetype, including some examples from our fieldwork, follows. The order is largely predicated on the extent to which we believe that the archetypes can and do play leading roles in the food-marketing renaissance and the broader welfare of the marketing system.

\section{Hopeful Desperates}

Many people and families-single producers or sellers in the region-simply do not have the skill or resources to function in the increasingly sophisticated food-marketing system that has emanated from the remnants of Yugoslavia. Generally rural, poorly educated, and closer to production in the value chain, they often tend to continue habits that they know well and once rewarded them. An example from Pristina helps illustrate this point: The area surrounding Pristina is known for the quantity and quality of its peppers. Under the old system, farmers simply brought their produce to a drop-off point, an exchange venue, or a market determined by the state. Despite the disappearance of that market and no well-informed expectation for its return, many farmers continue to bring their produce to this site, with the hope that someone or some institution will purchase them. Indeed, many peppers still are sold there, but this new, unsubsidized market cannot absorb the excess capacity, resulting in lower prices, spoilage, waste, and producerseller despondency. More chilling is the condition whereby some farmers must work in fields laden with mines and explosive ordnance. Without policies and programs to retrain these people, to rid unexploded ordnance, and to assist with marketing-system development, the future for Hopeful Desperates is not bright. In an exceptionally resource-strapped region, comprehensive government programs are not likely to be forthcoming. Nongovernmental organizations, multilateral aid agencies, and the private sector must intervene and remedy such problems.

\section{Dinosaurs}

Dinosaurs are organizations, sometimes quite large and with a venerable history, that operate with mind-sets that are reminiscent of the prewar days when the region was still one country and the government provided markets. They can be thought of as the organizational equivalent of Hopeful Desperates. We are reluctant to share precise names of firms, but many firms-some large baked-goods companies, some dairies, and the like-continue to wait for government subsidies and markets by government fiat. At a more macro or policy level, the Croatian government provides another example: The government intends to push ahead with the aforementioned plan to construct wholesale markets throughout the country. These facilities will provide both wholesale and retail service. Suppliers will be able to transact with resellers. There also will be an adjacent green market in which resellers will transact with final consumers. 
This plan and its proponents, though well intentioned, do not recognize how rapidly retailing is consolidating, driven by major chain retailers. These plans and companies that rely on government-sponsored plans exemplify the Dinosaurs, the organizations that are likely to be extinct soon because they have not responded to market forces.

\section{Tycoons}

The large corporations that account for most of the food processing and manufacturing in the Balkans seem to exhibit two distinct profiles as they proceed through privatization to a marketing orientation. First are the firms that received significant government support through the privatization process; they now enjoy the benefits of capitalization necessary to fuel growth and of good connections with policymakers. Agrokor-a large, diversified food processor, manufacturer, and retailer-exemplifies the Tycoons. Tycoons consider their most important competitive advantage their knowledge of the Balkans, access to the best vestiges of the old system, consumer familiarity with and preferences for their brands, superior human resources (key managers were trained abroad in multinational corporations and universities), commitment to information technology, and focus on brand development and market growth, not only regionally but in Europe in general and even globally. Tycoons' competitors and sometimes their customers often claim that they have received unfair preferential treatment from the government and that they can dictate terms to suppliers and retailers. Nevertheless, Tycoons continue to wield greater influence. Although they tend to dominate various food-marketing sectors at this time, they are likely eventually to experience intense competition in the forms of other vertically integrated marketing behemoths from the EU and the United States as domestic markets continue to open.

\section{Oldies but Goodies}

Other large firms that are historically successful and have loyal customers seem to have received less favorable treatment and suffer from undercapitalization. The Podravka Group, another large food manufacturer with beloved brands (recall Vegeta), is traveling a more difficult road to privatization and competitiveness. This firm typifies the Oldies but Goodies. Danica, Podravka's processed meat division, provides a good example. Danica has strong brand loyalty, domestically and regionally, but is unable to meet consumer demand because it cannot access adequate supplies of raw materials. This unfortunate reality as we indicated previously is partly due to the decimated domestic livestock industry and partly due to import restrictions; however, the overarching constraint is undercapitalization. Oldies but Goodies are in a precarious position. They have valuable assets and loyal consumers but few resources to leverage them and to increase their businesses. Without consolidation, rationalization, or foreign direct investment, it is difficult to envision a long-term positive outlook for them. However, foreign direct investment is possibly an attractive option because it would enable the local firms and their familiar products and brands to remain in existence, which would benefit large numbers of stakeholders throughout the food marketing system.

\section{Phoenix Entrepreneurs}

Despite numerous constraints, there is an evolving and growing entrepreneurial spirit among many firms. In many cases, these Phoenix Entrepreneurs literally have risen from the ashes, similarly to the mythical Phoenix bird. They are typically small, market-oriented firms-that is, micro enterprises and small and medium-sized enterprises. They most commonly are found in the production and retailing sectors, in which barriers to entry are lower than the more capitalintensive activities of processing, manufacturing, and distribution. We have interviewed scores of Phoenix Entrepreneurs over the past decade, and we are struck by the extraordinary variety of their activities, their resourcefulness, and their perseverance. Subsequently, we share just a few examples of the types of Phoenix Entrepreneurs that are making important contributions to food marketing and broader socioeconomic development.

Gljiva d.o.o. produces delicacy mushrooms in an abandoned railroad tunnel. The firm supplies domestic demands, but its relative closeness to Italy enables export to a larger and less price-sensitive market. The firm has benefited from a joint venture with a U.S. organization and a local government-supported incubator for private small and medium-sized enterprises, Eko-Liburnia.

Gospoja, which operates on Island Krk in the Adriatic $\mathrm{Sea}$, is a family-owned, integrated winery. It has been among the first wine producers to adopt organic production processes. Moreover, it enjoys $30 \%-40 \%$ annual growth. Demand exceeds supply; to date, it has no incentive to establish a distribution network for its products because tourists, principally German and Austrian, purchase the inventory on site at the Gospoja restaurant and shop.

In Kosovo, Pestove consolidated land holdings of several farmers and tapped into the Kosovar Diaspora in the Netherlands to secure Dutch capital and a genetic strain of Dutch potatoes (larger and more disease resistant) for export to the EU. Demonstrating marketing and management savvy to investors, the owner-manager of Pestove received additional capital to build a value-added factory to produce ready-made, frozen, sliced potatoes for export. He plans to expand into fertilizer distribution and farm machinery sales.

Lasko Pivo is a family-owned brewery in Slovenia that continues to grow throughout the region, trumpeting the purity of its water and other ingredients, its Slovenian independence, and its distinct colors and logo, all while fending off larger international brewers that have descended on the regional market.

Vegafruit and Lijanovici, which we previously discussed, are also excellent examples of Phoenix Entrepreneurs, which now are important players in the food-marketing system. They create jobs, generate revenue, add value through quality products, and build bridges to formerly hostile groups throughout the region. Lijanovici is using a multilingual Internet site to reach out to global customers. The success of these companies is remarkable, given that both emerged during severe crises in the most contentious and difficult regions.

Finally, regardless of Phoenix Entrepreneurs' many contributions, we would be remiss if we failed to state that not everyone appreciates their success. For example, precisely 
because Lijanovici has reached out to former enemies through goods and services, hard-line nationalists in the community have dissented, sometimes violently. Two weeks before our last interview with the Lijanovici management team, an assassination attempt was made on the president of the company. Although it failed, we were reminded that the process to stability, peace, and mutual prosperity sometimes lurches rather than sprints forward.

\section{Channel Leaders}

The firms characterized as Tycoons and Phoenix Entrepreneurs are emerging as channel leaders (cf. Etgar 1977). They are facilitating organization and integration, developing the production sectors, and streamlining distribution and retailing. We have described constraints that retard the development of critical value-added food-processing and manufacturing sectors. Furthermore, along with the countries of the region that all have shifted to the market, an evolving and sometimes unpredictable legal environment, as well as corruption, also affects the marketing system. The channel leaders are succeeding despite these constraints because they perceive their missions as solutions to these problems; indeed, they tend to perceive many of the problems as opportunities. Tycoons have economies of scale; leverage over most players in the channel; brand equity; and superior government relations, management, and marketing vision. Phoenix Entrepreneurs succeed because they are supremely market oriented, nimble, and receptive to "things that work," which often are counter to conventional methods and political and cultural resistance. They have products demanded by consumers at the end of channels, and thus larger players within the channel-players on which these entrepreneurs often rely-are more willing to accommodate the preferences of Phoenix Entrepreneurs.

\section{Other Factors for Success}

Previously, we mentioned factors that contribute to successes for Tycoons and Phoenix Entrepreneurs, including market orientation, relationship management, development of differential advantages, and brand equity - in short, fundamental mechanisms well understood by many market leaders the world over. However, these mechanisms are not so well understood by the majority of managers in the remnants of Yugoslavia, and these managers lack managerial acumen, support systems, and other resources to affect desirable outcomes to the benefit of consumers and the market. Furthermore, there are other important factors that tend to be more macro factors, including policies, that seem to play a role in success. We briefly discuss these macro factors next.

\section{Level of Destruction}

The extent to which a country or area within a country was devastated by the war is a strong predictor for food system recovery and the broader recovery of the entire country or area. That all of Slovenia and Croatia's Istrian Peninsula were almost unscathed has helped them recover quickly. Moreover, neither has a large population of dislocated people trying to assimilate and to enter an already tight labor market. However, counterintuitive examples can be found in which the level of destruction actually stimulated domestic and foreign aid to help recovery, and this had some initial successes, such as the restoring of some municipal buildings in Vukovar. Whether such successes can be sustained remains to be seen. Nevertheless, the areas relatively undamaged and without traumatized people have recovered more quickly.

\section{Transition and Transparency}

All the countries are transitioning to more market-oriented economies and, concomitantly, to more transparent marketing and political systems - that is, more clear, open, and public processes that deter corruption and stimulate fairness and stakeholder inclusion. However, in general, the countries and regions that have made more widely systemic shifts to the market (i.e., Slovenia, Croatia, parts of Macedonia, and a few parts of Bosnia-Herzegovina) and have also created more-transparent marketing and political systems are faring better. An important offshoot of greater transparency is a greater sense of ownership by the populace and a sense that ingenuity, hard work, and integrity will not only enhance the probability for individual success but also contribute to society and make it better. Greater transition and transparency also are important for foreign direct investment and other forms of constructive involvement by foreign countries and institutions.

\section{Geographic Luck}

Physical location is a predictor for success. Some countries and regions simply are geographically "lucky." For example, Slovenia borders Italy and Austria. In addition to having easy access to the large and wealthy market for food exports, Slovenia is an investment destination for EU countries. Trade and investment with the EU forces greater transparency, market orientation, and compatible systems. Regular commercial interactions with the EU create a new and different national psyche, one focused on integration, cooperation, tolerance, and inclusion. These outcomes collectively create a snowball effect, stimulating still more trade and investment, and broader systemic progress and development occur more rapidly. Slovenia was invited to join the EU before any other countries of the former Yugoslavia, and this was no accident-nor are its more impressive development indicators. ${ }^{10}$ Macedonia has some similar advantages because it borders Greece, though simmering disagreements over which country owns the Macedonia "brand" have created a chill between the two countries, which hampers greater cooperation. ${ }^{11}$

Parts of Croatia are less than an hour from Italy, and Croatia borders Slovenia, which works to Croatia's advantage compared with most of the rest of the former Yugoslavia to the east and south. Moreover, Croatia has other geographically desirable assets-namely, the Dalmatian Coast, a widely known tourist destination that annually pours billions of dollars into the economy; much of that

\footnotetext{
10Slovenia became a member of the EU on May 1, 2004.

${ }^{11}$ Greeks refer to Macedonia as the Former Yugoslav Republic of Macedonia, or FYROM, not Macedonia, which they believe is a name and region distinctly and uniquely Greek.
} 
money is spent on food, wine, and entertainment. Montenegro has similar but more remote coastal assets.

Bosnia-Herzegovina, Serbia, and Kosovo are markedly less lucky. Each is landlocked and farther from welldeveloped EU members. To varying degrees, each also wrestles with internal tensions, deep political intrigue, and issues about national identity. In summary, they are less transparent in general and often are less willing to comply with EU and global standards for various systems that affect marketing. Thus, their development lags accordingly, which brings us to the next factor.

\section{External Involvement: Anchors in Global Systems}

Countries and regions that have been more open to farreaching and systemic external involvement have recovered more rapidly. Essentially, they seek anchors in recognized and supported global systems and policies. A first link often tends to be Diaspora - that is, a connection to an ethnic group scattered around the world. Although the stimulus for the initial connection to this group may be cultural affinity and trust, our research indicates that the real value of the Diaspora is its understanding of and appreciation for effective policies and practices in more stable and prosperous markets and societies and a desire to share and to implement such policies and practices in the "home" country. An infusion of financial, intellectual, managerial, and entrepreneurial capital results.

As local organizations become more aware of EU and global standards for conduct and performance, they also become more aware of consumer expectations in export markets and of ways to connect with these consumers. They then begin to target them and to seek conduits that are linked to their food-marketing system, and then they demand more from that system. In addition to increasing the customer base, this system has the added benefit of enhancing a company's or a brand's domestic image. The owner of a Croatian wine company summarized this idea as follows:

The issue is not really greatly increasing our volume of sales to the US, EU, or Japan. We don't even have the capacity (for that strategy), but if we can just sell a few bottles in these markets, then our local customers say, "They sell to the US and EU, the quality must be very good." This helps us to increase sales here.

Other important anchors have proved to be international banks, universities and their linkage programs, and, in general, any organization or institution that can share various forms of capital, knowledge, and practices that tend to be effectual or at least are recognized as acceptable standards in the global marketplace. The extent to which countries and regions in the recovering Balkans buy into them, or "anchor" their systems into them, tends to enhance various socioeconomic systems, particularly food-marketing systems and, more broadly, societal welfare.

\section{Conclusion}

Our research indicates that market-oriented, integrative food-marketing systems indeed help mitigate and even transcend ethnic hostilities in the countries and regions that currently constitute the remnants of the former Yugoslavia. Furthermore, policies and conditions that nurture food- marketing systems tend to enhance food security and population stability and also to stimulate employment, institution building, economic growth, global inclusion, sustainable development, technology transfer, and quality of life for the people of the region. In turn, these outcomes augment stability and/or better resource management in adjacent countries in the Balkans, the EU, and the broader global community. Despite these promising findings and the guarded cause for optimism that they instill, several challenges still must be overcome.

Food and agribusiness form a major national strategic initiative throughout the region; yet food systems still are in various stages of transition. Throughout the channel, there is evidence of successful adoption of marketing orientation, but many barriers exist, most notably capitalization and infrastructure devastation due to the most recent wars. An additional barrier is indigenous cultural forces, such as daily shopping, limits on land ownership, and sometimes vested interests in older policies and systems versus more efficient market-based economies. These entrenched values and practices can be a considerable impediment to more efficient food distribution throughout the region. Consumers in the poorest regions of the Balkans spend a disproportionately large amount of their incomes on food, which is counter to rapid economic development.

It is imperative for the food-marketing system to become more efficient so that consumer spending and public programs can be directed at other growth-stimulating sectors. Market forces are in place to foster this change, but policy directives and better incentives that link key elements of the domestic and global marketing system must also be implemented. To date, modeling more developed economies and/ or responding to prudent directives from governments, academic institutions, multilateral aid organizations, and investors in ways that ensure mutually beneficial development goals hold promise as sound policy considerations Countries and regions throughout the war-ravaged Balkans that have adopted such policies are now experiencing greater efficiency in their food-marketing systems and thus improved societal outcomes.

\section{References}

Aaker, J., V. Benet-Martinez, and J. Garolera (2001), "Consumption Symbols as Carriers of Culture: A Study of Japanese and Spanish Brand Personality Constructs," Journal of Personality and Social Psychology, 81 (3), 492-508.

Abbott, J.C. (1962), "The Role of Marketing in the Development of Backward Agricultural Economies," Journal of Farm Economics, 44 (2), 349-62.

April, Jay E., David J. Rogers, Gilvert N. Hersh, and Charles Slater (1974), "Consumerism-A Neglected Decision Tool for Solving Problems in Developing Countries," in Marketing Systems for Developing Countries, Dov Israeli, Dafna Israeli, and Frank Meissner, eds. New York: John Wiley \& Sons, 70-80.

Bartels, Robert and Roger L. Jenkins (1977), "Macromarketing," Journal of Marketing, 41 (October), 17-20.

Belk, R. and G. Ger (1994), "Problems of Marketization in Romania and Turkey," in Research in Consumer Behavior: Consumption in Marketizing Economies, Vol. 7, C. Shultz, R. Belk, and G. Ger, eds. Greenwich, CT: JAI Press, 123-56. 
Bicanic, R. (1973), Economic Policy in Socialist Yugoslavia. New York: Cambridge University Press.

Boger, S., J.E. Hobbs, and W.A. Kerr (2001), "Supply Chain Relationships in the Polish Pork Sector," Supply Chain Management: An International Journal, 6 (2), 74-82.

Central Intelligence Agency (2004), The World Factbook, (accessed March 7, 2004), [available at http://www.cia.gov].

Cohen, Lenard (1993), Broken Bonds: The Disintegration of Yugoslavia. Boulder, CO: Westview.

Collier, P., L. Elliot, H. Hegre, A. Hoeffler, M. Reynal-Querol, and N. Sambanis (2003), Breaking the Conflict Trap: Civil War and Development Policy. Washington, DC: The World Bank.

Dahringer, Lee (1983), "Public Policy Implications of Reverse Channel Mapping in Lesotho," Journal of Macromarketing, 3 (1), 69-75.

Didzarevic, Zlatko (1993), Sarajevo: A War Journal. New York: Fromm International.

Doder, Dusko (1978), The Yugoslavs. New York: Random House.

Donja, Robert and John Fine (1994), Bosnia \& Hercegovina: A Tradition of Betrayal. New York: Columbia University Press.

Douglas, M. and B. Isherwood (1978), The World of Goods: Towards an Anthropology of Consumption. New York: Norton.

Drucker, Peter (1958), "Marketing and Economic Development," Journal of Marketing, 22 (January), 251-59.

Etgar, Michael (1977), "Channel Environment and Channel Leadership," Journal of Marketing Research, 15 (February), 69-76.

European Bank for Reconstruction and Development (1999), EBRD Transition Report. Sidcup, UK: Janet Matthews Information Services.

Fisk, George (1981), "An Invitation to Participate in Affairs of the Journal of Macromarketing," Journal of Macromarketing, 1 (1), 3-6.

Gleditsch, Nils Petter, Peter Wallensteen, Mikael Eriksson, Margareta Sollenberg, and Håvard Strand (2002), "Armed Conflict 1946-2001: A New Dataset," Journal of Peace Research, 39 (5), 615-37

Glenny, Misha (1992), The Fall of Yugoslavia: The Third Balkan War. New York: Penguin.

$$
\text { (2000), The Balkans. New York: Viking Press. }
$$

Goldman, A. (1974), "Outreach of Consumers and Modernization of Urban Food Retailing in Developing Countries," Journal of Marketing, 38 (October), 8-16.

Gorton, M., E. Hirschman, and J. Bauman (1996), "The Birth of Modern Entitlement Programs: Reports from the Field and Implications for Welfare Policy," Journal of Public Policy \& Marketing, 15 (Fall), 263-77.

Holbrook, M. (1999), "Higher Than the Bottom Line: Reflections on Some Recent Macromarketing Literature," Journal of Macromarketing, 19 (1), 33-45.

—_ and E. Hirschman (1982), "The Experiential Aspects of Consumption: Consumer Fantasies, Feelings, and Fun," Journal of Consumer Research, 9 (September), 132-40.

__ and T. Kuwahara (1998), "Collective Stereographic Photo Essays: An Integrated Approach to Probing Consumption Experiences in Depth," International Journal of Research in Marketing, 15 (3), 201-221.

Holbrooke, R. (1998), To End A War. New York: Random House.
Holton, Richard H. (1953), "Marketing Structure and Economic Development," Quarterly Journal of Economics, 67 (August), 344-61.

Holtzman, J. (1986), "Rapid Reconnaissance Guidelines for Agricultural Marketing and Food System Research in Developing Countries," International Development Working Paper No. 30. East Lansing: Michigan State University.

Hunt, Shelby (1981), "Macromarketing as a Multidimensional Concept," Journal of Macromarketing, 1 (1), 7.

Jelavich, Barbara (1996), History of the Balkans: Eighteenth and Nineteenth Centuries. New York: Cambridge University Press.

Klein, T. and R. Nason (2001), "Marketing and Development: Macromarketing Perspectives," in Handbook of Marketing and Society, P. Bloom and G. Gundlach, eds. Thousand Oaks, CA: Sage Publications, 263-97.

Kumcu, E. and M.E. Kumcu (1987), "Determinants of Food Retailing in Developing Economies: The Case of Turkey," Journal of Macromarketing, 7 (2), 26-40.

Layton, R. (1981), “A Macromodel of Trade Flows," Journal of Macromarketing, 1 (1), 35-48.

Lincoln, Y.S. and E.E. Guba (1985), Naturalistic Inquiry. Newbury Park, CA: Sage Publications.

Lydall, H. (1989), Yugoslavia in Crisis. New York: Oxford University Press.

Macesic, G. (1964), Yugoslavia: The Theory and Practice of Development. Charlottesville, NC: University of Virginia Press.

Marquardt, R. and T. Burkink (2002), "Trends in Natural Food Sales and Consumer Food Choices," Complementary Health Practices Review, 7 (3), 209-220.

McCracken, G. (1988), The Long Interview. Newbury Park, CA: Sage Publications.

Meade, William K. and Robert Nason (1991), "Toward a Unified Theory of Macromarketing: A Systems Theoretic Approach," Journal of Macromarketing, 11 (Fall), 72-82.

Model, J. and T. Haggerty (1991), "The Societal Impact of War," Annual Review of Sociology, 17, 205-224.

Olsen, J. and K. Granzin (1994), "Vertical Integration and Economic Development: An Empirical Investigation of Channel Integration," Journal of Global Marketing, 7 (3), 7-39.

Peace Pledge Union (2000), "PPU Armed Conflicts Profiles 1998/ 2000," (March 10, 2004), [available at http://www.ppu.org.uk/ wars/n-text/n-index.html].

Pecotich, A., N. Renko, and C. Shultz (1994), "Yugoslav Disintegration, War, and Consumption in Croatia," in Research in Consumer Behavior: Consumption in Marketizing Economies, Vol. 7, C. Shultz, R. Belk, and G. Ger, eds. Greenwich, CT: JAI Press, 1-27.

Perko-Separavic, I. (1983), Technology, Power, Self-management. Zagreb, Croatia: State Press.

Rekacewicz, P. and C. Marin (2000), "The Changing Shape of Yugoslavia (1815-1999)," La Monde diplomatique, (March 5, 2004), [available at http://mondediplo.com/maps/ yugoslaviamdv49].

Rocco, F. (1989), "The Place and Role of Marketing in Yugoslav Theory and Practice," in Essays on the Yugoslav Economic Model, G. Macesic, L. Rikard, and D. Vojnic, eds. New York: Praeger Publishers, 71-82. and R. Obraz (1963), Market Research-Marketing.
Zagreb, Croatia: Informator. 
Rusinow, Dennison (1977), The Yugoslav Experiment: 1948-1974. London: C. Hurst.

Sharma, Arun and Luis V. Dominguez (1992), "Channel Evolution: A Framework for Analysis," Journal of the Academy of Marketing Science, 20 (1), 1-15.

Shultz, C. (1997), "Improving Life Quality for the Destitute: Contributions from Multiple-Method Fieldwork in War-Ravaged Transition Economies," Journal of Macromarketing, 17 (1), 56-67.

and A. Pecotich (1997), "Marketing and Development in the Transition Economies of Southeast Asia: Policy Explication, Assessment, and Implications," Journal of Public Policy \& Marketing, 16 (Spring), 55-68.

, and K. Le (1994), "Changes in Marketing Activity and Consumption in the Socialist Republic of Vietnam," in Research in Consumer Behavior: Consumption in Marketizing Economies, Vol. 7, C. Shultz, R. Belk, and G. Ger, eds. Greenwich, CT: JAI Press, 225-57.

Silber, Laura and Allan Little (1997), Yugoslavia: Death of a Nation. New York: Penguin.

Simmie, J. and J. Deleva (1991), Yugoslavia in Turmoil: After SelfManagement. London: Pinter Publishers.

Slater, C. (1968), "Marketing Processes in Developing Latin American Societies," Journal of Marketing, 32 (July), 50-53.

(1974), "Marketing in Developing Societies," paper presented at INCOMAS Conference, Tel Aviv, Israel (January 6-11).

Stern, Louis W. and Adel I. El-Ansary (1996), Marketing Channels. Upper Saddle River, NJ: Prentice Hall.

Tanner, M. (1997), Croatia: A Nation Forged in War. New Haven, CT: Yale University Press.
Thomas, Vinod and John Nash (1991), Best Practices in Trade Policy Reform. Washington, DC: The World Bank.

The United Nations (2003), "The Former Yugoslavia," (accessed March 30, 2004), [available at http://www.un.org/Depts/ Cartographic/map/profile/frmryugo.pdf].

Vaile, R., E. Grether, and R. Cox (1952), Marketing in the American Economy. New York: Ronald Press.

Vojnic, D., R. Land, and B. Marendic (1989), "The Socioeconomic Model of Socialist Self-management," in Essays on the Yugoslav Economic Model, G. Macesic, R. Land, and D. Vojnic, eds. New York: Praeger Publishers.

Vugrinec-Hitrec, V. (1983), "Marketing Self-Management Socialist Science?" Osvrti, 864-73.

Wallendorf, M. and R.W. Belk (1989), "Accessing Trustworthiness in Naturalistic Consumer Research," in Interpretive Consumer Research, E.C. Hirschman, ed. Provo, UT: Association for Consumer Research, 69-84.

Wilkie, W. and E. Moore (1999), "Marketing's Contribution to Society," Journal of Marketing, 63 (Special Issue), 198-218.

- and (2003), "Scholarly Research in Marketing: Exploring the '4 Eras' of Thought Development," Journal of Public Policy \& Marketing, 22 (Fall), 116-46.

Wood, Nicholas (2004), "Kosovars Survey the Damage of Ethnic Violence," The New York Times, (March 21), 4.

The World Bank (2002a), "Agriculture Recovery and Food Security," working group report. Washington, DC: The World Bank.

(2002b), "Reconstruction of Bosnia and Herzegovina: Priorities for Recovery and Growth," press release, The World Bank. 